\title{
Impact in Earnings Management of Fair Value Measurement Based on Electric Power Industry
}

\author{
Xiaoyan $\mathrm{Liu}^{1} \&$ Yanqing $\mathrm{Yu}^{1}$ \\ ${ }^{1}$ School of Economics and Management, North China Electric Power University, Beijing, China \\ Correspondence: School of Economics and Management, North China Electric Power University, Beijing, \\ China. E-mail: 1liu716@sina.com
}

Received: June 6, 2013

Accepted: June 26, 2013

Online Published: July 25, 2013

doi:10.5539/ibr.v6n8p49

URL: http://dx.doi.org/10.5539/ibr.v6n8p49

\begin{abstract}
Earnings management has always been the focus of Accounting Research, but under the new accounting standards, the introduction of fair value may create space for earnings management of listed companies. The existence of earnings management behavior in the power industry, which is a pillar industry in China's national economy, is related to the healthy and orderly development of China's national economy. Based on the related financial data from 2006 to 2011 of listed companies in electric power industry and from investment income and asset impairment losses two aspects, this paper uses descriptive statistics analysis and regression analysis method for empirical research, and then found the existence of earnings management behavior in the power industry. According to conclusions, this paper puts forward relevant suggestions for related information users to analyzing or making decision offering support.
\end{abstract}

Keywords: fair value measurement, earnings management, the electric power enterprise

\section{Introduction}

Since the 1980s, earnings management has been the focus of accounting research, domestic and foreign scholars did a lot of research on the judgment of the earnings management, earnings management motivation, earnings management means, earnings management of the economic consequences and investors reaction. The Ministry of Finance issued a new system of accounting standards in February 15, 2006, and put into practice in listed companies in January 1, 2007. Compared with the old standards, the biggest bright spot of the new accounting standards should be the introduction of fair value measurement attribute, creating the possibility of earnings management of listed companies.

Along with our country's market economy rapid development and its knowledge updated-speed unceasing enhancement, the fair value measurement attribute has become more and more important on improving the relevance of accounting information. As the application scale of fair value is expanding constantly in domestic and international, more and more relevant accounting standards at the fair value issued. Thus the means of earnings management caused by fair value measurement model may relate to more aspects.

Researches on the influence of fair value to earnings management in domestic have not been involved in electric power industry, but electric power industry has the distinct industry characteristics among other industries in our country. As a typical natural monopoly industry, the electric power industry belongs to one of the public sectors, characterizing natural monopoly and publicity. With the implementing of the anti-monopoly law tin August 1, 2008 , the traditional electric power enterprises of monopoly advantage is gradually reduced. In order to alleviate the contradiction between supply and demand of electric power, the electric power industry needs to increase investment, so as to greatly increase the fund demand. Under the premise of expanding fund demand and the wakening support of national policy, the electric power enterprises only by making full use of the present domestic capital market rich resources and developing diversified financing channels can they ensure enterprises fund use efficiency and market competitiveness. Upon the above reasons, electric listed companies may be engaged in diversified management and set foot in unfamiliar industry, so there may be the phenomenon of earnings management.

Based on the principle of importance and combined with the electric power industry characteristics, this paper will only to analyze the fair value of several most widely influential samples. We will study the correlation 
between each accounting subject which influence profit and retained profits in the relativity analysis, so as the income statement items. The related income statement items meanwhile give enlightenment for linear regression in each explanatory variable. According to the linear relationship between fair value measurement and the listed company earnings management, we can analyze the earnings management phenomenon in electric power enterprise of the listed companies, and put forward related suggestions for improvement.

\section{Literature Review}

The Statement of Financial Accounting Standards No. 157 issued by FASB defined fair value as a market participant sells an asset or paid or transfers a liability in an orderly transaction at the measurement day to obtain corresponding gains. International Accounting Standards Board regards fair value as the amount that parties who are familiar with situation are willing to exchange assets or liabilities in true and fair transaction (IASB, 1998). In comparison, the fair value measurement has more advantage than historical cost measurement. It can provide more relevant and timely accounting information. In China's current market economy environment, only some aspects of accounting measurement use fair value measurement. Fair value as the new criterion of a new part, standard setters endowed with more policy option. Accounting standards of the flexibility and incompleteness make enterprises accounting has certain independent judgment and choice of space. GaoWei's research (2010) shows that free choice of fair value standards left space for the opportunism.

Different people have different views from different perspectives on earnings management. Integrated all sorts of views, the general sense of the earnings management is defined as: enterprises' top management authorities on one hand follow generally accepted accounting principles and other related laws and regulations, on the other hand control or regulate the foreign report of accounting earnings information by changing the accounting treatment methods, the choice of accounting policies, and other means, so as to mislead other stakeholders to achieve the group interest maximization and enterprise benefit maximization.

Domestic and overseas researches have made great achievements on fair value measurement attribute of earnings management. Haw et al. (1998), through to our county securities market "earnings management" situation of empirical research, found that the listed companies in China is mainly through the control of "below-the-line" to achieve the allotment of the SFC conditions, that is, through the investment income, non-operating revenue and expenditure and profits of non-core business projects. Francis et al. (1996) \& Rees et al. (1996), on the voluntary asset impairment companies' research, demonstrated the presence of earnings management behavior by weak evidence. Chinese scholars WeiTao, Zhengfei Liu \& Hongwei Shan(2007) found whether loss or profit the company's earnings management is quite rely on non-recurring items by studying the behavior of China 's listed companies using non-recurring gains and losses to manage earnings. The loss companies mainly want to stop losses and avoid losses, but the profit only want to smooth the profits. The study of Wang wei, Zhanchi Wu \& Luoshao De (2009) shows that securities investment income has value relevance, but do not have timeliness, and the listed companies carry out earnings management on realized securities investment income through selling time choice. Xiangjun $\mathrm{Lu}(2010)$ through the research of the impact of the fair value to the financial statements of listed companies, found that changes in the fair value, gain on debt restructuring have a great influence on part of companies in current profit. GaoWei (2010) elaborated on the application range of the fair value of the new accounting standards, which mainly perform in the investment real estate, the non-monetary assets exchange, the financial tools and the debt restructuring. She also analyzed the space of earnings management in this valuation mode. XieHua \& Liping Gao(2011) from both the positive and negative ways illustrated that fair value measurement accords with the trend of the development of our country, and through the empirical study proved that fair value measurement and financial listed companies' earnings management have linear relationship.

\section{Empirical Analysis}

\subsection{Research Hypothesis}

On the basis of the above theory, from the income statement items on the view, fair value measurement for profit effects mainly displays in the changes in the fair value gains and losses, non-operating revenue and expenditure, assets impairment losses and investment income and so on several aspects. Since the object of this paper is the power industry listed companies, combined with its characteristics, this paper decided to study two major accounting items which bring a significant impact to the profit through corresponding accounting treatment. Based on signal transmission theory, investment income will eventually transfer to current profit or loss, thereby affecting current profit or loss, so does the asset impairment loss. Two assumptions are made on this basis.

Hypothesis 1: Investment income and listed companies' earnings management phenomenon are positively related. 
Hypothesis 2: Asset impairment loss and listed companies' earnings management phenomenon are negatively related.

\subsection{Model Selection and Sample}

For earnings management in the empirical research, we often use linear regression method to study the various variables mainly about the relationship between accrued profit and net profit, and focus on listed companies using nonrecurring items to adjust the listed companies' profits. The focus of our research is centered on nonrecurring items measured at fair value, so this paper used model (1) as regression model in order to highlight the impact on net profit.

$$
Y=\beta 0+\beta 1 X 1+\beta 2 X 2+\beta 3 X 3+\beta 4 X 4+g
$$

Model (1): Y: net profit/ year-end net assets

$\mathrm{X} 1$ : operating profit/year-end net assets

$\mathrm{X} 2$ : asset impairment loss/ year-end net assets

$\mathrm{X} 3$ : investment income/ year-end net assets

$\mathrm{X} 4$ : non-operating income / year-end net assets

This article selects the electric power industry of the listed companies of A-share market as the research object, observing $2006 \sim 2011$ years of financial data, making descriptive statistics of each trend graph of the ratio of total profit to operating income, investment income, asset impairment losses firstly and then carrying out correlation and regression analysis. In order to guarantee the sample data effective, we excluded ST and * ST companies and data missing companies as well as power companies which have just listed in recent years, ensuring that the samples are in relatively mature stage. Since the total profit of negative will make securities investment income accounted for the proportion of total profit performance anomaly, and also does not meet the test of earnings management " deficits motivation", so this article excludes the total profit of the negative sample companies and select the final 48 samples. All the data is from CCER financial database and Sina financial network. In analyzing the data, SPSS 17.0 software is used.

\subsection{Experimental Analysis Results}

\subsubsection{Descriptive Statistics Analysis}

To better understand the influence of fair value measurement on listed companies of the power industry after the promulgation of the new guidelines, through observing the change trends of the ratio of several specific items of income statement in total profit, the possible start points of listed companies of the power industry on earnings management can be observed visually. Using this method, we can not only observe the existence of earnings management, but also can know its universality and direction.

Based on 48 listed companies in the power industry from the year of 2006 to 2011, this paper shows the ratio chart of operating profit to total profit investment income to total profit asset impairment loss to total profit in order to understand the influence degree of listed companies of the power industry and the existence of earnings management. As shown in Figure 1, Figure 2, Figure 3.

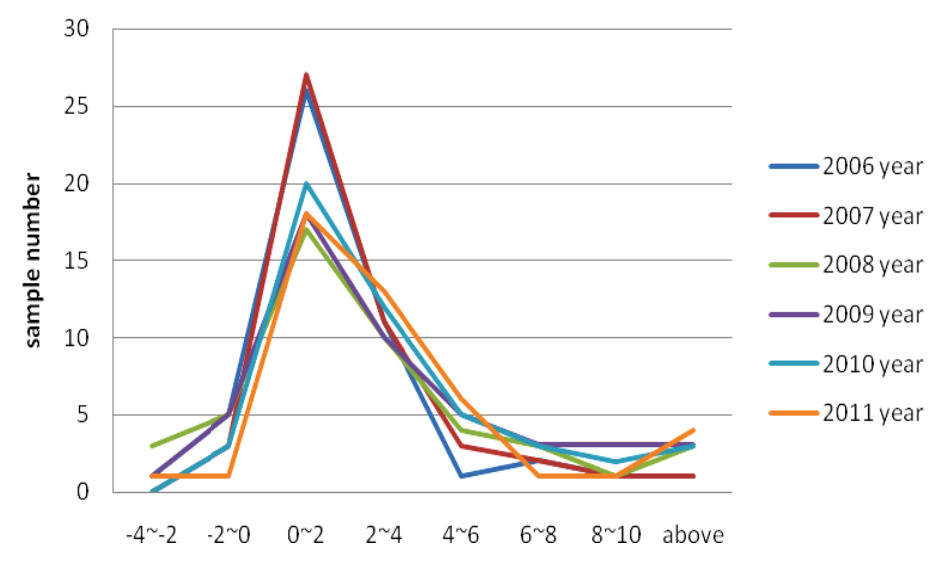

Figure 1. The ratio of operating profit to total profit (\%) 


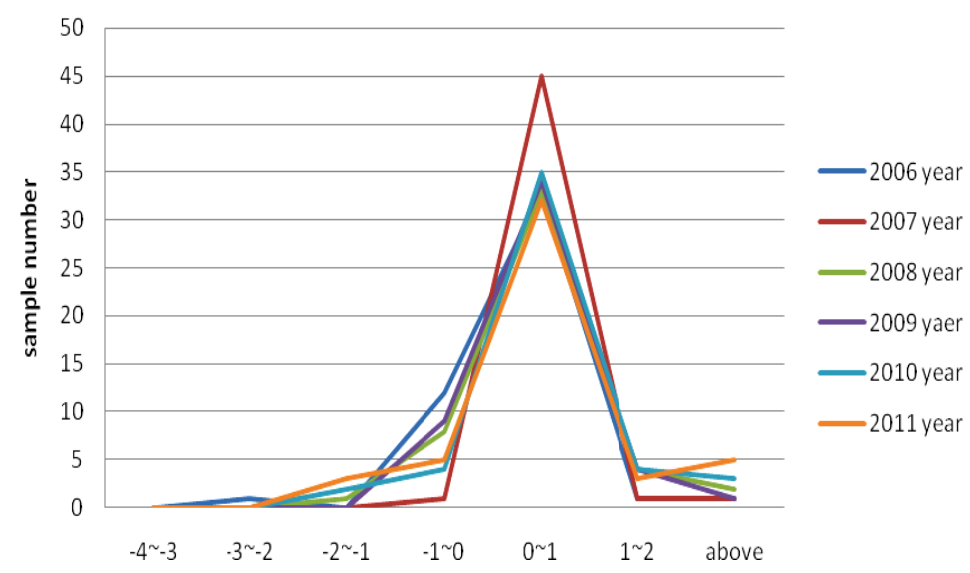

Figure 2. The ratio of investment income to total profit (\%)

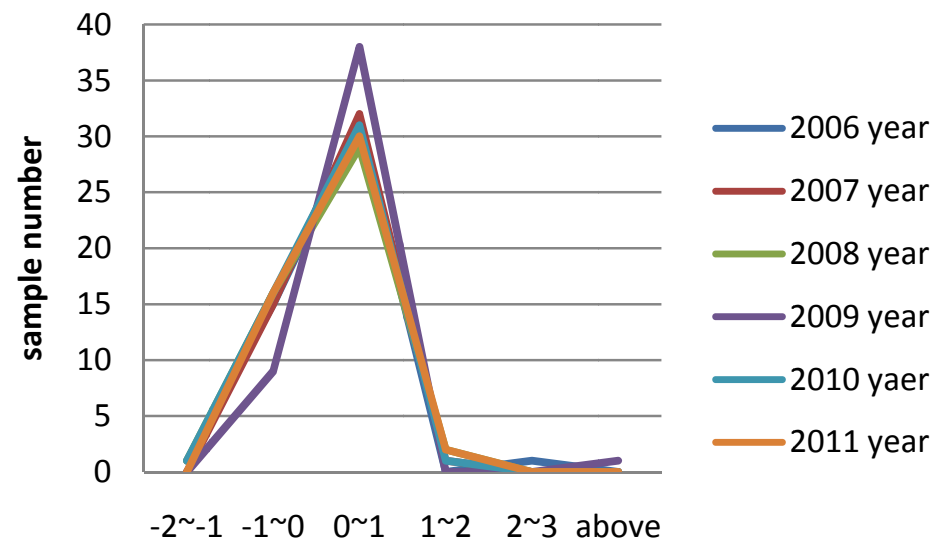

Figure 3. The ratio of asset impairment to total profit (\%)

From a normal ratio of view, i.e. from 0 to 1, we can observe that in Figure 1 the number of sample companies generally downward trend, especially for the year of 2008. That may be subject to the impact of the financial crisis; from Figure 2, we can clearly observe that the sample number has little change, but showing an upward trend with the increase in the proportion, especially after 2009, that is more obvious. As for Figure 3, the sample number in each ratio stage has little change.

Upon the above analysis, we know that the operating income of the electric listed companies in the proportion of main business declined and the earnings management exists.

\subsubsection{Regression Analysis}

Usually, profit from principal operations is the main way to changes in the profits of listed companies, not associated with the change amount of non-recurring items with fair value measurement. In the variable relationship, it should be positively correlated with the difference between the net profit and operating profit, but not related with the difference of changes in fair value, the difference of non-operating revenue and expenditure, and the difference of assets impairment loss. But in the presence of earnings management, those non-recurring items would have relationship with net income. From the descriptive statistical analysis, we just intuitively feel the abnormal of power industry listed companies profit ratio. In order to gain a deeper understanding of the impact of these items on earnings management, Regression analysis will be used to test this case. The analysis results as the table 1 shows:

From table 1, we can find that the coefficient of investment income is positive $(0.705)$ with $\mathrm{t}(10.988)$ and sig. (0.000) in model 1, indicating $\mathrm{Y}$ and $\mathrm{X} 3$ are significantly positively related at 0.01 level, so the hypothesis 1 has been verified. The coefficient of asset impairment loss variation is negative $(-0.184)$ with $t(-2.854)$ and sig.(0.007), indicating $\mathrm{Y}$ and $\mathrm{X} 2$ are negatively related at 0.01 level, verifying the hypothesis 2 and illustrating the selected sample companies reduced profits by provision of asset impairment. 
Table 1. Stepwise regression equation coefficient table

\begin{tabular}{|c|c|c|c|c|c|c|}
\hline \multicolumn{2}{|c|}{ model } & \multicolumn{2}{|c|}{ Un-standardized Coefficients } & \multirow{2}{*}{$\begin{array}{l}\text { Standardized Coefficients } \\
\text { Beta }\end{array}$} & \multirow[t]{2}{*}{$\mathrm{t}$} & \multirow[t]{2}{*}{ Sig. } \\
\hline & & $\mathrm{B}$ & Std. Error & & & \\
\hline \multirow[t]{5}{*}{1} & (Constant) & -.017 & .004 & & -4.221 & .000 \\
\hline & $\mathrm{X} 1$ & .466 & .053 & .871 & 8.827 & .000 \\
\hline & $\mathrm{X} 2$ & -1.331 & .467 & -.184 & -2.854 & .007 \\
\hline & $\mathrm{X} 3$ & .889 & .081 & .705 & 10.988 & .000 \\
\hline & $\mathrm{X} 4$ & .436 & .069 & .624 & 6.296 & .000 \\
\hline
\end{tabular}

From the chart we can see that each explanatory variable of significance level is less than 0.001 , indicating that the explanation variables are significantly related to net-profit changes. The coefficient of investment income is positive (0.518) with $\mathrm{t}(23.206)$, indicating that investment income is significantly positively related to net profit. The coefficient of asset impairment loss is negative (-0.421), indicating that the loss of asset impairment is significantly negatively related to net profit. Therefore this paper holds that the selected sample companies have more widely adopted measurement instruments measured at fair value to adjust profits, especially by way of investment income. This also from another angle proved this hypothesis.

\section{Conclusions}

Through the empirical research, we can prove that the third parts of the two assumptions are established:

1) Investment income and listed companies' earnings management phenomenon are positively related.

2) Asset impairment loss and listed companies' earnings management phenomenon is negatively related.

Research not only shows that there is earnings management phenomenon in the electric power enterprises, but also distinctly perform in the use of investment income and asset impairment loss of earnings management. Since the study on earnings management phenomenon of the power enterprises at home and abroad is less and less, so this case can't cause enough attention. This phenomenon reflects the operating income of the electric listed companies in the proportion of main business declined, and also from the side reflects the electric power enterprises "proper job" behavior. In order to prevent or reduce a lot of ulterior motives people using the fair value measurement for earnings management, on the one hand, we should strengthen the fair value theory research, and establish higher level fair value measurement criteria; On the other hand, to improve accounting personnel professional moral level and professional quality, establishing sufficient internal and external supervision. For the electric power enterprises, the electricity revenues decide the business operation of the power plate, so keeping main business income stable, healthy growth is the main security of the power plate listed companies. If electric listed companies are engaged in diversification business, they should be more cautious to the new industry which they have never set foot in, to promote the healthy and stable development of the market-oriented reforms of the electricity industry.

\section{References}

Francis, J., Hanna, J. D., \& Vincent, L. (1996). Causes and Effects of Discretionary Asset Write - Offs. Journal of Accounting Research, 7, 134. http://dx.doi.org/10.2307/2491429

Gao, W. (2010). The fair and equitable value measurement model of the surplus management. Journal of GanSu Province Science and Technology, 26(13), 32-36.

Haw, I. M., Daqing, Q., Woody, I., \& Wu, W. G. Z. (1998). Earnings Management of Listed Firms In Response to Security Regulations In China. S Emerging Capital Market. Working paper. Hong Kong Chinese University.

$\mathrm{Lu}, \mathrm{X}$. (2007). Western fair value accounting review empirical study. Journal of Modern Management Science, $11,100-102$.

$\mathrm{Lu}, \mathrm{X}$. (2010). The fair value of the listed company, and the influence of the financial statement. Journal of Cooperative Economy, Science and Technology, 9, 76-93.

Rees, L., Gill, S., \& Gore, R. (1996). An investigation of asset write - downs and concurrent abnormal accruals. Journal of Accounting Research, 34, 157-169. http://dx.doi.org/10.2307/2491431

Tao, W., Liu, Z., \& Shan, H. (2007). The current profit and loss of earnings management motivation, method and effect - from Chinese listed company empirical evidence. Management of the world, 1 .

Wang, W., Wu, Z., \& De, L. (2009). The value of securities investment income correlation and surplus 
management. Accounting Research, 6.

Yakov, A., \& Kefei, L. (2006). The declining information content of dividend announcement and The effects of Institutional Investors. Forthcoming Journal of Financial and Quantitative, 35, 1-12.

Zhang, M. (2013). A Fuzzy Description Logic with Statistical Default Inference. International Journal of Digital Content Technology and its Applications, 7(1), 50-57. http://dx.doi.org/10.4156/jdcta.vol7.issue 1.6

Zhu, L., \& Xie, H. (2011). Fair value measurement of the listed company, and the influence of earnings management - based on the financial industry research. Wuxi Commercial Vocational and Technical College Journal.

\section{Copyrights}

Copyright for this article is retained by the author(s), with first publication rights granted to the journal.

This is an open-access article distributed under the terms and conditions of the Creative Commons Attribution license (http://creativecommons.org/licenses/by/3.0/). 